\title{
Preponderant agent, what is that?
}

Submitted: $01 / 04 / 2015$

Revised: $17 / 04 / 2015$

Accepted: $22 / 04 / 2015$
Clara Luz Álvarez*

\begin{abstract}
Purpose - Preponderant agent is a new instrument for preventing and reverting adverse impact in competition due to highly concentrated markets. Therefore, this paper's objective is to present and analyze the preponderant agent concept in Mexico with emphasis on the broadcast sector, the telecommunication regulator decisions and the courts' interpretation.
\end{abstract}

Methodology/approach/design - The objectives were achieved by researching and analyzing the main legal documents, the Congress reports and debates, the regulator's decisions and other relevant regulator's documents, as well as final decisions by the courts in connection with broadcast sector.

Findings - Among the findings are that certain topics were not duly addressed by the Mexican regulator, or by the Congress, whereas the courts were more willing to hold decisions in favor of public interest based on constitutional intent and deference to the regulator's decision.

Originality/value - This paper will be valuable for persons interested in telecommunications, broadcast and antitrust. Although the preponderant agent concept created in Mexico is not necessarily a "best practice", it does provide an alternative instrument in antitrust. Moreover, the courts decisions also provide criteria regarding regulatory deference for the regulator.

Keywords: telecommunications, broadcast, antitrust, preponderant, significant market power.

*Member of the Mexican National Researchers System (level II) and researcher of the Universidad Panamericana (Mexico). She received the National Journalism Award for spreading democratic culture for its program Código Democracia at the Congress Channel (2014). Clara Luz is author of the books Derecho de las Telecomunicaciones (3rd ed., 2014) and Internet y Derechos Fundamentales (2011), and coordinator of the book Telecomunicaciones y Tecnologías de la Información (2012). She was rapporteur for the International Telecommunications Union's study group of ICT accessibility for persons with disabilities (2006-2011), and Commissioner for the Mexican Telecommunications Commission (Cofetel). Email: claraluzalvarez@gmail.com. Website: www.claraluzalvarez.org. 


\section{Introduction}

Mexico's telecommunication and broadcast sectors are highly concentrated in a few corporate groups. This is the result of building a country after the Mexican Revolution started on 1910 - based on monopolistic interests on a local, regional and national level (Alvarez, 391). ${ }^{1}$ Since capital formation and economies of scale were so vital in developing a functional infrastructure, the government deemed competition as against the public interest and licenses were granted on a discretionary basis (Alvarez, 389-394).

The Mexican 1990s was characterized by privatizations and economic liberalization, and telecommunications were no exception. Privatizations included the telecom historic operator and public monopoly, Telmex (1990), a public TV broadcasting network (Imevisión - Channels 7 and 13, 1993), and the satellite monopoly known as Satmex, in 1997 (Alvarez, 396-400, 407-409). The Telecommunications Law enacted in 1995 (now repealed) opened the telecom sector to competition. Increased competition was supposed to improve the quality of services, increase access and lower prices.

Although two decades have passed since the opening of the Mexican telecom market, the sector is still dominated by a few powerful players:

- $\quad$ Fixed telephony = América Móvil (Telmex): $71 \%$ of subscribers. ${ }^{2}$

- $\quad$ Fixed data = América Móvil (Telmex): $60.2 \%$ of subscribers. ${ }^{3}$

- $\quad$ Mobile telephony = América Móvil (Telcel): $69 \%$ of subscribers. ${ }^{4}$

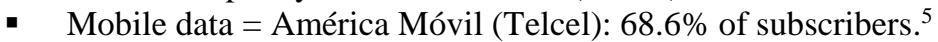

- $\quad$ Pay TV = Grupo Televisa: $60.1 \%$ of subscribers ${ }^{6}$

- Free-to-air TV = Grupo Televisa: $70 \%(2012)^{7}$ average share of transmissions computed from the beginning of the transmission to the end of it.

${ }^{1}$ Example in telecommunications can be found on the Ley de Vías Generales de Comunicación (1940).

${ }^{2}$ Instituto Federal de Telecomunicaciones, Informe estadístico 3 Trimestre 2014, http://www.ift.org.mx/iftweb/wp-content/uploads/2015/03/InformeEstadisticoVF.pdf, p. 18.

${ }^{3}$ Ibidem, p. 23.

${ }^{4}$ Ibidem, p. 27.

${ }^{5}$ Ibidem, p. 35 .

${ }^{6}$ Ibidem, p. 38.

${ }^{7}$ Instituto Federal de Telecomunicaciones, Resolución mediante la cual el Pleno del Instituto Federal de Telecomunicaciones determina al grupo de interés económico del que forman parte Grupo Televisa S.A. B., Canales de Televisión Populares, S.A. de C.V., Radio Televisión, S.A. de C.V., Radiotelevisora de México Norte, S.A. de C.V., T.V. de los Mochis, S.A. de C.V., Teleimagen del Noroeste, S.A. de C.V., Televimex. S.A. de C.V., Televisión de Puebla, S.A. de C.V., Televisora de Mexicali, S.A. de C.V., Televisora de Navojoa, S.A., Televisora de Occidente, S.A. de C.V., Televisora Peninsular, S.A. de C.V., 
The Mexican telecom reform (2013-2014) purport to tackle the effects of such high concentrations inter alia through the creation of a new regulator with antitrust faculties and against whose decisions there could be no injunction, and through the determination of preponderant agents to which special obligations would be imposed to prevent adverse effects to competition.

This article addresses the concept of preponderant agent, its origins and objective of establishing it in the Mexican Constitution. Then the determination made by the Mexican telecom regulator (Instituto Federal de Telecomunicaciones, IFT) will be analyzed, along with the arguments presented in both telecommunications and in broadcast for declaring certain corporate groups and affiliates, as part of the economic interest group to be held as a preponderant agent. The differences in telecom and broadcast for calculating each groups with more than $50 \%$ national participation on its respective sector, will be presented, analyzed and criticized.

Afterwards the courts' decision and criteria for the preponderant agent in broadcast will be explored, highlighting the relevance for the IFT considering the high regulatory deference in judicial proceedings that is expected to continue. Certain special obligations imposed in for the preponderant agent in broadcast will be analyzed, namely, those regarding relevant audiovisual content and advertisement.

Finally, this article ends with some remarks that include those regarding preponderant agent concept, the effectiveness of special obligations, the absence of plurality analysis by regulator, the regulatory deference precedent thanks to the courts resolution over preponderant agents, and additional facts like the recently concluded public bid for free-to-air commercial TV, that might have consequences over preponderant agent determination in the broadcast sector.

Mario Enríquez Mayans Concha, Televisión La Paz, S.A., Televisión de la Frontera, S.A., Pedro Luis Fitzmaurice Meneses, Telemisión, S.A. de C.V., Comunicación del Sureste, S.A. de C.V., José de Jesús Partida Villanueva, Hilda Graciela Rivera Flores, Roberto Casimiro González Treviño, TV Diez Durango, S.A. de C.V., Televisora de Durango, S.A. de C.V., Corporación Tapatía de Televisión, S.A. de C.V., Televisión de Michoacán, S.A. de C.V., José Humberto y Loucille, Martínez Morales, Canal 13 de Michoacán, S.A. de C.V., Televisora XHBO, S.A. de C.V., TV Ocho, S.A. de C.V., Televisora Potosina, S.A. de C.V., TV de Culiacán, S.A. de C.V., Televisión del Pacífico, S.A. de C.V., Tele-Emisoras del Sureste, S.A. de C.V., Televisión de Tabasco, S.A. y Romana Esparza González, como agente económico preponderante en el sector radiodifusión y le impone las medidas necesarias para evitar que se afecte la competencia y la libre concurrencia, Pleno, $\mathrm{V}$ Sesión Extraordinaria 2014, P/IFT/060314/77, March 6, 2014, p. 408, http://apps.ift.org.mx/publicdata/P_IFT_EXT_060314_77.pdf (Consultation date: Nov. 11, 2014). 


\section{Preponderant agents concept}

Preponderant agent (agente económico preponderante) is a new instrument introduced in the Mexican Constitution by the telecom reform (2013) which purports to identify economic agents with excessive market power and impose special obligations to cope with such power through a fast-track procedure. The IFT was mandated to determine those carriers in the telecom and the broadcast sectors that hold more than $50 \%$ of national participation in such services based on the number of users, audience, network traffic or capacity.

What was the rationale for determining that more than $50 \%$ was an adequate percentage for a carrier to be preponderant? There is no evidence for the reasons to establish such percentage neither in the bill nor in the legislative process documents. ${ }^{8}$ Nonetheless, it appears as a very high percentage if compared with what the European Union (EU) once had in place. In 1998 the EU approved a Directive whereby an agent with more than $25 \%$ of market share was considered as with significant market power and had special obligations (e.g. interconnection $)^{9}$. Such provision was superseded with the enactment of the new electronic communications framework (2002), as that regulation:

"[provisions prior to the new electronic communications network] has proved effective in the initial stages of market opening as the

${ }^{8}$ See (1) Iniciativa de Decreto que reforma y adiciona diversas disposiciones de la Constitución Política de los Estados Unidos Mexicanos, presented by president Enrique Peña Nieto to the Mexican Deputy Chamber on March 11, 2013; (2) Cámara de Diputados - Comisión de Puntos Constitucionales, Proyecto de Dictamen en sentido positivo a la iniciativa con proyecto de Decreto que reforma y adiciona diversas disposiciones de los artículos $6^{\circ}, 7^{\circ}, 27,28,73,79$ y 94 de la Constitución Política de los Estados Unidos Mexicanos, en materia de telecomunicaciones, March 15, 2013, (3) Cámara de Diputados - Comisión de Puntos Constitucionales, Propuestas de modificación al Dictamen de la Comisión de Puntos Constitucionales con proyecto de Decreto por el que se reforman y adicionan diversas disposiciones de la Constitución Política de los Estados Unidos Mexicanos en materia de telecomunicaciones, March 21, 2013; and (4) Senado de la República, Dictamen de las Comisiones Unidas de Puntos Constitucionales; de Comunicaciones y Transportes; de Radio, Televisión y Cinematografía y de Estudios Legislativos, con la opinión de las Comisiones de Gobernación y de Justicia, respecto de la Minuta con proyecto de Decreto por el que se reforman y adicionan diversas disposiciones de la Constitución Política de los Estados Unidos Mexicanos en materia de telecomunicaciones, April 23, 2013.

${ }^{9}$ See Directiva 98/10/CE del Parlamento Europeo y del Consejo de 26 de febrero de 1998 sobre la aplicación de la oferta de red abierta (ONP) a la telefonía vocal y sobre el servicio universal de telecomunicaciones en un entorno competitivo, published on the European Communities Official Daily L 101/24 ES on April 1, 1998, http://www.boe.es/doue/1998/101/L00024-00047.pdf (Consultation date: March 15, 2015). 
threshold for ex ante obligations, but now needs to be adapted to suit more complex and dynamic markets". ${ }^{10}$

The preponderant concept was included in the Mexican Constitution as follows:

The Instituto Federal de Telecomunicaciones must determine preponderant economic agents in the broadcast and telecommunication sectors, and shall impose those special obligations which are necessary to avoid that free competition is affected and, hence, end users are also affected. Such special obligations shall be enacted in a term not to exceed one hundred and eighty calendar days computed from its [the IFT] integration, and shall include if applicable, obligations related with information, offer and quality of the services, exclusivity agreements, limitations on the use of equipment between networks, asymmetric obligations upon tariffs and network infrastructure, including unbundling of network essential elements and, if applicable, accounting separation, functional and structural separation of such agents.

For the purposes set forth in this Decree, an economic agent will be deemed as preponderant based on its national participation in providing broadcast or telecommunication services, if it directly or indirectly holds more than fifty percent of national participation computed such percentage by the number of users, subscribers, audience, network traffic or by the capacity used by its network, pursuant to the data that the Instituto Federal de Telecomunicaciones has. ${ }^{11}$

The constitutional text refers in the same section to both "sectors" and "services" to determine a preponderant agent. Whether this calculation is based on sector or services, the results could be very distinct. Based on sector, for example, América Móvil (holding company of Telmex and Telcel) would be the preponderant agent in the telecommunication sector. Televisa, on the other hand, would not be preponderant, as it does not hold a majority share in radio broadcasting. If based on services, however, both América Móvil (fixed and

${ }^{10}$ See Directive 2002/21/EC of the European Parliament and of the Council of 7 March 2002 on a common regulatory framework for electronic communications networks and services (Framework Directive), number 25, http://eur-lex.europa.eu/legalcontent/EN/TXT/PDF/?uri=CELEX:02002L0021-20090702\&from=EN (Consultation date: March 15, 2015).

${ }^{11}$ Decreto por el que se reforman y adicionan diversas disposiciones de los artículos $6^{o}$, $7^{\circ}$, 27, 28, 73, 78, 94 y 105 de la Constitución Política de los Estados Unidos Mexicanos, [Decree by which several provisions of articles $6^{\circ}, 7^{\circ}, 27,28,73,78,94$ and 105 of the Political Constitution of the United Mexican States are amended or added], published in the Federal Official Daily on June 11, 2013, article Eighth transitory section III. 
mobile telephony and internet access) and Televisa (free-to-air TV and pay TV) would be deemed preponderant carriers in several services.

\section{IFT preponderant determination}

When the IFT ruled that América Móvil and Televisa were each preponderant agents in telecommunications and broadcasting, the new Mexican Telecom Law had not yet been enacted (Ley Federal de Telecomunicaciones y Radiodifusión, LFTR), nor was there any specific procedure to follow. Consequently, the IFT initiated an administrative process to determine the preponderant agent, including a preliminary report. The preliminary report was notified to the agents that were considered to be preponderant; then these had the opportunity to respond to the preliminary report and to offer evidence to assert their positions; and finally, the IFT solved the issue with the final resolution that determined which companies were part of the preponderant agents in telecom and in the broadcast sector. ${ }^{12}$

\footnotetext{
${ }^{12}$ See (1) Instituto Federal de Telecomunicaciones, Resolución mediante la cual el Pleno del Instituto Federal de Telecomunicaciones determina al grupo de interés económico del que forman parte América Móvil, S.A.B. de C.V., Teléfonos de México, S.A.B. de C.V., Teléfonos del Noroeste, S.A. de C.V., Radiomóvil Dipsa, S.A.B. de C.V., Grupo Carso, S.A.B. de C.V., y Grupo Financiero Inbursa, S.A.B. de C.V., como agente económico preponderante en el sector de telecomunicaciones y le impone las medidas necesarias para evitar que se afecte la competencia y la libre concurrencia, Pleno, V Sesión Extraordinaria, P/IFT/EXT/060314/76, March 6, 2014, www.ift.org.mx/iftweb/sector-detelecomunicaciones/ (Consultation date: (Nov. 20, 2014); and (2) Instituto Federal de Telecomunicaciones, Resolución mediante la cual el Pleno del Instituto Federal de telecomunicaciones determina al grupo de interés económico del que forman parte Grupo Televisa S.A.B., Canales de Televisión Populares, S.A. de C.V., Radio Televisión, S.A. de C.V., Radiotelevisora de México Norte, S.A. de C.V., T.V. de los Mochis, S.A. de C.V., Teleimagen del Noroeste, S.A. de C.V., Televimex, S.A. de C.V., Televisión de Puebla, S.A. de C.V., Televisora de Mexicali, S.A. de C.V., Televisora de Navojoa, S.A., Televisora de Occidente, S.A. de C.V., Televisora Peninsular, S.A. de C.V., Mario Enríquez Mayans Concha, Televisión La Paz, S.A., Televisión de la Frontera, S.A., Pedro Luis Fitzmaurice Meneses, Telemisión, S.A. de C.V., Comunicación del Sureste, S.A. de C.V., José de Jesús Partida Villanueva, Hilda Graciela Rivera Flores, Roberto Casimiro González Treviño, TV Diez Durango, S.A. de C.V., Televisora de Durango, S.A. de C.V., Corporación Tapatía de Televisión, S.A. de C.V., Televisión de Michoacán, S.A. de C.V., José Humberto y Loucille, Martínez Morales, Canal 13 de Michoacán, S.A. de C.V., Televisora XHBO, S.A. de C.V., TV Ocho, S.A. de C.V., Televisora Potosina, S.A. de C.V., TV de Culiacán, S.A. de C.V., Televisión del Pacífico, S.A. de C.V., Tele-Emisoras del Sureste, S.A. de C.V., Televisión de Tabasco, S.A. y Ramona Esparza González, como agente económico preponderante en el sector radiodifusión y le impone las medidas necesarias para evitar que se afecte la competencia y la libre concurrencia, Pleno, V Sesión Extraordinaria, P/IFT/EXT/060314/77, March 6, 2014, www.ift.org.mx/iftweb/sector-de-radiodifusion/ (Consultation date: Nov. 11, 2014).
} 
In order to determine that América Móvil was preponderant, the IFT first declared that the economic interest group was composed by America Móvil (holding of Telmex and Telcel), Telmex (fixed telephony and data), Telcel (mobile telephony and data), Grupo Carso (holding of commercial, industrial, energy, infrastructure and construction sector companies ${ }^{13}$ ), and Inbursa (financial group). ${ }^{14}$ Then it essentially made an addition of the number of subscribers of the main telecommunication services concluding that such companies were preponderant agents in telecommunications.

Declaring Televisa as preponderant agent in broadcast presented more challenges for the IFT than América Móvil case for several reasons. The first challenge was to determine which companies and persons were part of the economic interest group of Televisa. Televisa holds title to several licenses for free-to-air TV channels along the Mexican Republic commonly known as Canal de las Estrellas (channel 2), Canal 4, Canal 5 and Canal 9 (hereinafter "Televisa Channels"). ${ }^{15}$ But these channels are also retransmitted in several cities by independent free-to-air TV licensees in which Televisa does not hold any stock or share. IFT named these independent free-to-air TV licensees as "independent affiliates" as will be explained below. ${ }^{16}$

${ }^{13}$ Grupo Carso, http://www.carso.com.mx/ES/grupo_carso/Paginas/perfilcorporativo.aspx (Consultation date: March 25, 2015).

${ }^{14}$ Neither Grupo Carso, nor Inbursa hold any title to a telecom license, nor are they telecom carriers. IFT considered that they were companies with commercial and financial interests which coordinated activities for a common end and for the economic benefit of their shareholders. Instituto Federal de Telecomunicaciones, Resolución mediante la cual el Pleno del Instituto Federal de Telecomunicaciones determina al grupo de interés económico del que forman parte América Móvil, S.A.B. de C.V., Teléfonos de México, S.A.B. de C.V., Teléfonos del Noroeste, S.A. de C.V., Radiomóvil Dipsa, S.A.B. de C.V., Grupo Carso, S.A.B. de C.V., y Grupo Financiero Inbursa, S.A.B. de C.V., como agente económico preponderante en el sector de telecomunicaciones y le impone las medidas necesarias para evitar que se afecte la competencia y la libre concurrencia, Pleno, V Sesión Extraordinaria, P/IFT/EXT/060314/76, March 6, 2014, www.ift.org.mx/iftweb/sector-de-telecomunicaciones/ (Consultation date: (Nov. 20, 2014), p. 156.

${ }^{15}$ These channels are the channel numbers in Mexico city, as they may vary from city to city.

${ }^{16}$ Instituto Federal de Telecomunicaciones, Resolución mediante la cual el Pleno del Instituto Federal de Telecomunicaciones determina al grupo de interés económico del que forman parte Grupo Televisa S.A.B., Canales de Televisión Populares, S.A. de C.V., Radio Televisión, S.A. de C.V., Radiotelevisora de México Norte, S.A. de C.V., T.V. de los Mochis, S.A. de C.V., Teleimagen del Noroeste, S.A. de C.V., Televimex, S.A. de C.V., Televisión de Puebla, S.A. de C.V., Televisora de Mexicali, S.A. de C.V., Televisora de Navojoa, S.A., Televisora de Occidente, S.A. de C.V., Televisora Peninsular, S.A. de C.V., Mario Enríquez Mayans Concha, Televisión La Paz, S.A., Televisión de la Frontera, S.A., Pedro Luis Fitzmaurice Meneses, Telemisión, S.A. de C.V., Comunicación del Sureste, S.A. de C.V., José de Jesús Partida Villanueva, Hilda Graciela Rivera Flores, Roberto 
Televisa's economic interest group was declared upon:

- 12 subsidiaries or affiliates owned by Televisa or in which Televisa holds stock. These entities operate 226 TV stations.

- 30 independent affiliates in which Televisa does not hold any stock or share. These independent affiliates operate 32 stations (18 relay station transmitting the same signals, and 14 local stations).

The relationship between Televisa and the independent affiliates is as follows: (1) Televisa pays the independent affiliates a fix percentage of the advertisement sales and the independent affiliates must retransmit Televisa Channels, and (2) independent affiliates may enter into licensing agreement with Televisa in connection with other contents different from those included in Televisa Channels. To be considered an independent affiliate by the IFT, the station must retransmit at least $40 \%$ of the audiovisual content of Televisa Channels.

IFT argued that, despite Televisa holds no equity on the independent affiliates, they have commercial and financial common interests regarding programming and advertisements. Such common interests makes Televisa hold a real power over the independent affiliates, and at the same time the independent affiliates have all the incentives to comply with Televisa's demands. Televisa and the independent affiliates share the benefits of advertisement profits; Televisa increases its audience and hence the value of advertisement in Televisa Channels; Televisa also receives income for licensing other programs to the independent affiliates and these benefits them because they do not incur in production costs. Independent affiliates claimed that they also produced their own content and advertisement different from Televisa, but they were unable to prove that fact before the IFT. ${ }^{17}$

Casimiro González Treviño, TV Diez Durango, S.A. de C.V., Televisora de Durango, S.A. de C.V., Corporación Tapatía de Televisión, S.A. de C.V., Televisión de Michoacán, S.A. de C.V., José Humberto y Loucille, Martínez Morales, Canal 13 de Michoacán, S.A. de C.V., Televisora XHBO, S.A. de C.V., TV Ocho, S.A. de C.V., Televisora Potosina, S.A. de C.V., TV de Culiacán, S.A. de C.V., Televisión del Pacífico, S.A. de C.V., Tele-Emisoras del Sureste, S.A. de C.V., Televisión de Tabasco, S.A. y Ramona Esparza González, como agente económico preponderante en el sector radiodifusión y le impone las medidas necesarias para evitar que se afecte la competencia y la libre concurrencia, Pleno, V Sesión Extraordinaria, P/IFT/EXT/060314/77, March 6, 2014, www.ift.org.mx/iftweb/sector-de-radiodifusion/ (Consultation date: Nov. 11, 2014), pp. 207-211.

${ }^{17}$ Idem. 
"The fact that the independent affiliate entities retransmit GTV [Televisa's] programming represents a reduction of the costs that independent affiliates incur, the maximum exploitation of such resource and the profit of the economies of scale in the content production, [all of] which translates in more benefits for both parties.

(...) The above considerations imply a big risk for the independent affiliates of receiving less income in connection with those obtained from the transmission of GTV programming or even of having losses or putting the business existence in risk, if they stop transmitting the programming that depends or is significantly equal to GTV programming. Therefore, the "independent" affiliates have all the incentives to respond to GTV interests and GTV exercises a real power over the affiliates whose programming is made by a high percentage of GTV programming channels.

(...) moreover in the event that the independent affiliates transmit some content produced by their own or acquired to third parties (including advertisement), GTV programming content is the one that secures a significant part of the independent affiliates advertisement income when they retransmit a high percentage of GTV programming channels.

Consequently, it is estimated that independent affiliate stations with $40 \%$ or more of its programming of GTV channels are in a situation as described in the parapraphs above. That because the stations' operations profit is made up, in a significant way, of the same manner as the transmitted programming (...)." ${ }^{18}$

The second challenge was to provide sufficient reasoning for determining a preponderant of the broadcast sector based on free-to-air commercial TV, but excluding free-to-air radio and free-to-air non-for-profit TV. ${ }^{19}$

For excluding radio, the IFT made a comparison between free-to-air radio and TV influence, income and patterns of consumption. IFT ruled inter alia that: free-to-air TV was far more concentrated than radio and hence was more able to significantly affect competition; TV was the main media of information access $(73 \% \mathrm{TV}, 37 \%$ radio); people were more exposed to $\mathrm{TV}$ $(90 \%)$ than radio $(76 \%)$ (Conaculta); advertisement on TV was the main way of commercializing products and services; TV held $85 \%$ of advertisement of the broadcast sector (CICOM); TV generated $86 \%$ of income whereas radio did only $14 \%$ (INEGI); $90 \%$ of the audience accessed TV in their home, whereas $58 \%$ accessed radio in their home. ${ }^{20}$

IFT excluded from the calculation of audience share the audience share related with non-for-profit free-to-air TV stations, provided that these (1) do not

\footnotetext{
${ }^{18}$ Idem.

${ }^{19}$ Idem.

${ }^{20}$ Ibidem, pp. 308-311.
} 
have any commercial or for profit objectives, (2) may not sell advertisements, (3) are not competitors of commercial free-to-air TV, and (4) provide a community service. The IFT observed that commercial free-to-air TV maximizes its profits regardless of non-for-profit TV audience, because companies may only advertise in commercial free-to-air TV channels. Additionally, non-for-profit were unable to affect competition as they are not competitors of commercial channels. Notwithstanding the above, the difference in audience share if not-for-profit TV was considered only varied $2 \%$ : Televisa audience share without considering not-for-profit stations equaled $67 \%$, and including such stations its share was $65 \% .^{21}$

The third challenge was that subscribers of a telecom service are easier to calculate because there are statistics of the number of fix or mobile lines, and there are agreements in place between the carrier and the subscriber (except for pre-paid mobile lines). On the other hand, measuring broadcast audience is not as objective as with telecom subscribers.

The IFT considered the number of persons which were able to receive free-to-air TV in the Mexican Republic, and the market audience share. The audience share is the percentage of persons that have access to a specific channel in relation with the total number of audience. Audience share is different from rating insofar as rating is based on the index of audience for a given channel. IFT based its findings in an audience research by IBOPE which took into account the audience from 6 to 23 hours.

It is important to note that different methodologies are employed to determine the audience share in free-to-air TV and free-to-air radio. In free-toair TV, there is a process for estimated audience through a device known as people meters. This device is installed in home TV sets of a statistical sample, and it records the channel/program being viewed and the number of spectators. Free-to-air radio audience is estimated by survey made by telephone or personally. These methodologies for assessing the share of audience in broadcast are not objective as counting number of users via the number of lines or the agreements in place as was the case for the telecom sector. ${ }^{22}$

The IFT took as reference for audience share the results of a study by IBOPE of 2012 as the proceeding had initiated in November 2013. IBOPE study bases its results in a representative sample of the Mexican Republic audience through the use of people meters in major cities (Mexico city, Guadalajara and Monterrey) and 25 other places.

${ }^{21}$ Ibidem, pp. 312-314.

${ }^{22}$ Ibidem, pp. 308-310. 
IBOPE studies had traditionally been used by Televisa to assess its audience share, and were used by Televisa in its report filed before the Mexican Stock Exchange. Afterwards, Televisa initiated litigation against IBOPE regarding an agreement between them. Consequently, Televisa challenged the appropriateness of IBOPEs study, and the IFT - and further the courts dismissed such claim as Televisa had in the past recognized IBOPE's results as valid.

The IFT also considered the number of users by network capacity (MHz/Population) to determine Televisa as preponderant. This metric takes into account the number of users able to receive free-to-air TV signals on the authorized coverage area, and the spectrum capacity $(6 \mathrm{MHz})$. Pursuant to this metric, Televisa had $54 \%$ of the $\mathrm{MHz}$ for free-to-air TV.

The IFT ultimately determined that Televisa (including its independent affiliates) was the preponderant in the broadcast sector, because (1) Televisa held $67 \%$ of the audience share, and (2) Televisa held $54 \%$ of the MHz of freeto-air TV.

A major criticism to IFT preponderant resolution regarding Televisa was that it did not include Televisa's pay TV companies. Notwithstanding that pay TV and free-to-air TV are related markets due to their audiovisual content and TV advertisement markets, IFT did not refer to Televisa's pay TV companies. In the case of America Móvil the IFT determined that Grupo Carso and Inbursa should be considered within that same economic interest group despite the fact that they did not hold title to any telecom license, yet IFT considered that as they had a strong relation with Telmex and Telcel, they had to be summoned to the preponderant proceedings. ${ }^{23}$ Following the same argument of América Móvil's resolution, why the IFT did not include Televisa's pay TV companies? The answer is unknown to the public. However, it could have been a political decision to omit any reference whatsoever to Televisa's pay TV companies so that none of the preponderant special obligations (analyzed below) would apply to them.

Currently, the IFT is conducting a research regarding Televisa's market power in pay TV market and preliminary determined that Televisa has significant market power in 2,124 pay TV local markets. ${ }^{24}$ This type of procedure has been in place since 1993, and the results in the Mexican telecom

\footnotetext{
${ }^{23}$ Instituto Federal de Telecomunicaciones, op. cit. 14 [Resolution of preponderant agent in telecommunication sector], pp. 156-157.

${ }^{24}$ Instituto Federal de Telecomunicaciones (Autoridad Investigadora), Datos relevantes del Dictamen Preliminar sobre la Existencia de Poder Sustancial en el Mercado Relevante de Provisión del Servicio de Televisión y Audio Restringidos, radicado en el Expediente AI/DC-001-2014, published in the Federal Official Daily on March 18, 2015.
} 
sector had been null until now. ${ }^{25}$ Although now the IFT has more scope of authority and no injunctions can be granted against IFT's decisions, IFT's investigation time and the procedure itself will take several months until its conclusion. After the final IFT decision as to whether Televisa has significant market power in pay TV, IFT would then be followed by another administrative procedure to impose special obligations to avoid abuse of its market power, consequently the effectiveness and timeliness of this procedure is still an open question.

\section{Judicial interpretation}

Against the preponderant decisions, several judicial review proceedings (juicios de amparo) were initiated before the specialized courts ${ }^{26}$ on March 2014 months before the new LFTR was enacted on July 2014. The main debate at Congress during the legislative process for approval of the LFTR was as to whether a preponderant agent should be considered by a whole sector or by single services. The Senate and Deputy Chamber reports regarding the LFTR proposed an interpretation that preponderant would be by sector rather than by services. The LFTR simply copied the constitutional provision regarding

${ }^{25}$ The former antitrust regulator (Comisión Federal de Competencia, Cofeco) declared on 1997 that Telmex was an agent with significant market power in several telecommunications markets. After one decade of litigation on 2007 Telmex won all litigations against such determination. On 2009 Telmex was once again declared by Cofeco as an agent with significant market power on several markets, but the former telecom regulator (Comisión Federal de Telecomunicaciones, Cofetel), never imposed special obligations to prevent abusive use of such market power. On 2010 Telcel was declared by Cofeco as an agente with significant market power on mobile telephony, but Cofetel failed to impose special obligations. See Alvarez, pp. 235-240.

${ }^{26} \mathrm{As}$ a result of the 2013 amendment to the Constitution, specialised courts for telecommunications, broadcasting and antitrust were created on August 10, 2013. See Consejo de la Judicatura Federal, Acuerdo General 22/2013 del Pleno del Consejo de la Judicatura Federal, relativo a la conclusión de funciones de los Juzgados Cuarto y Quinto de Distrito del Centro Auxiliar de la Primera Región, y su transformación como Juzgados Primero y Segundo de Distrito en Materia Administrativa Especializados en Competencia Económica, Radiodifusión y Telecomunicaciones, con residencia en el Distrito Federal, y jurisdicción territorial en toda la República. A la conclusión de funciones de los Tribunales Colegiados Segundo y Tercero de Circuito del Centro Auxiliar de la Primera Región y su transformación como Primer y Segundo Tribunales Colegiados de Circuito en Materia Administrativa Especializados en Competencia Económica, Radiodifusión y Telecomunicaciones, con residencia en el Distrito Federal y jurisdicción territorial en toda la República. Así como su domicilio, fecha de inicio de funcionamiento y a las reglas de turno, sistema de recepción y distribución de asuntos entre los Órganos Jurisdiccionales indicados. Y al cambio de denominación de la oficina de correspondencia común del Centro Auxiliar de la Primera Región., published on the Federal Official Daily on August 9, 2013. 
preponderant ad verbatim and described the special obligations that could be imposed to the preponderant in telecom and to the preponderant in broadcast.

Notwithstanding the above, the courts were only bound by the Constitution and not by the LFTR as it was enacted after the IFT preponderant resolutions.

Judicial resolutions over broadcast preponderant ${ }^{27}$ provide a very interesting approach by the courts in at least three aspects: the constitutional intent as how preponderant should be determined; the regulatory deference over IFT decisions that the courts are willing to accept; and the type of scrutiny that courts will likely have over telecom and antitrust regulators' decisions. ${ }^{28}$

\section{Preponderant's constitutional intent}

As pointed out in section "Preponderant agents concept" above, the Constitution is unclear whether the determination of a preponderant agent must be based on the whole sector or if it could be determined by a single service of a given sector. The final judicial decision acknowledged the ambiguity of the Constitution's wording, but confirmed IFT's decision based on the constitutional intent of the preponderant figure and on the expertise of the IFT as regulator for antitrust matters on telecom and broadcast. If the constitutional intent was to prevent negative effects on competition and hence to end users ${ }^{29}$, then that could be achieved by declaring Televisa as preponderant in the broadcast sector considering only free-to-air TV.

“(...) the Constitutional Assembly mentions preponderant agents, first, mandating the determination of preponderant economic agents "in the broadcast and telecommunications sectors" and, later, establishes that the agents must be determined based on their national participation "in providing broadcast or telecommunication services".

(...) Nonetheless, the ambiguity or lack of clarity in the constitutional wording does not discredit IFETEL's decision as to consider in the broadcast sector

${ }^{27}$ As of March 31, 2015 there are several final decisions of the specialized courts regarding lawsuits filed by different persons that are part of Televisa's economic interest group (as defined by the IFT). The lawsuit filed by Televisa is still pending final decision, as well as the resolutions regarding the lawsuits filed by America Móvil, Telcel, Telmex, Grupo Carso and Inbursa are also pending at the specialized courts for final resolution.

${ }^{28}$ In Mexico the IFT is the telecom and broadcast regulator with antitrust mandate over such sectors; the Comisión Federal de Competencia Económica (Cofece) is the antitrust regulator for all other sectors of the economy.

${ }^{29}$ Decreto por el que se reforman y adicionan diversas disposiciones de los artículos $6^{\circ}$, 7º 27, 28, 73, 78, 94 y 105 de la Constitución Política de los Estados Unidos Mexicanos, [Decree by which several provisions of articles $6^{\circ}, 7^{\circ}, 27,28,73,78,94$ and 105 of the Political Constitution of the United Mexican States are amended or added], published in the Federal Official Daily on June 11, 2013, article Eighth transitory section III. 
only free-to-air TV service, for determining preponderant [agent] as mandated in the relevant constitutional reform.

(...) the district judge's opinion is shared [by this court] regarding that the Constitution does not predetermine whether the determination of preponderant [agent] must be only one for each sector or whether it should refer to segments of such sector, or by each service, or by a combination of broadcast services, nor does it predetermine that there must be only one [preponderant] agent for each sector or several [preponderant agents], because the answer to these issues are not provided for in the Constitution.

(...) the justification of IFETEL's resolution subject to judicial review, is enough to hold on a reasonable manner the determination of the preponderant economic agent in the broadcast sector based only on free-to-air TV service, considering that [IFT] is a specialized entity, its decision is consistent with the end sought by the Constitutional Assembly and [within] the scope of its discretional faculties that it has to assess the facts and then act; additionally, [IFT] it justifies with reasons that appear admissible, the adequateness and reasonableness of its conclusions." 30

Both the lower and upper level courthouses dared to do what Congress did not: comply with the constitutional intent regardless of the political consequences for ruling against Televisa's interests.

\section{Regulatory deference and court's level of scrutiny}

One of the judicial resolutions regarding the judicial proceeding (juicio de amparo) of one independent affiliate, thoroughly developed the concept of regulatory deference by courts and the level of judicial scrutiny for regulators decisions. ${ }^{31}$ Consequently, this criteria is perhaps one of the most relevant for the future of the Mexican regulators in telecommunications and antitrust.

The specialized court ruled that IFT decisions in general must be upheld provided that they are reasonable and proportional. IFT as the telecom regulator has to make decisions making economic and technical assessments. Such decisions must be in line with the IFT mandates, and must not violate constitutional rights (e.g. due process, justification of the acts, and accuracy of facts) which could end up in unfairness. ${ }^{32}$

There are different types of discretionary competencies depending on what Congress enacted: major discretionary faculties are those in which there is

\footnotetext{
${ }^{30}$ Primer Tribunal Colegiado de Circuito en Materia Administrativa Especializado en Competencia Económica, Radiodifusión y Telecomunicaciones, Final resolution of revision remedy 65/2014 filed by Hilda Graciela Rivera Flores, February 26, 2015, paragraphs $302,303,318$ and 344.

${ }^{31}$ See Ibidem.

${ }^{32}$ Ibidem, paragraphs 349 and 357.
} 
no reference or terms that limit the regulator's decision; intermediate discretionary faculties are those that the regulator may exercise within the scope of interpretation of undefined legal concepts (conceptos jurídicos indeterminados ${ }^{33}$ ); and minor discretionary faculties allow the regulator to select its decision within those variables previously established by law. ${ }^{34}$

The discretionary competencies of IFT as regulator are those of technical nature, and consequently the level of scrutiny must be light. The technical nature and specialization makes courts defer to the regulator's decision, and to limit courts' participation to correct abusive or arbitrary actions. ${ }^{35}$

"In that regard, the discretionary competencies of the Administration, in this case of IFETEL (...) is linked with achieving public interest and it appears as objective, technical, with arguments and reasons, without having valid or solid reasons which evidence against them.

(...) considering the legitimacy presumption of the resolutions - highlighted in this same decision -, which is not effectively, nor directly objected by plaintiff and which must prevail over insufficient or unreasonable arguments, deference must be granted to the specialized authority criteria and decision, exercising only a light scrutiny in connection with scientific or technical issues addressed and acknowledging the validity of what has been decided [by the authority].

(...) the resolution subject to judicial review by plaintiff, issued by IFETEL, is an administrative act of discretionary nature in an intermediate degree, which complies with the limits of discretionary competencies reasonably exercised and in respect of which there must be a light scrutiny or deference to the Administration's will." 36

The regulatory deference and the standard of judicial scrutiny from the specialized courts would be applicable for IFT's decisions, except in those cases where Congress has established a less degree of discretionary competencies. This approach gives a sufficient degree of autonomy to the regulator, and if duly exercised, could amount to great benefits for public interest.

\footnotetext{
${ }^{33}$ The undefined legal concepts are those which meaning is vague, and must be interpreted. See Roldan Xopa, pp. 165-166.

${ }^{34}$ Primer Tribunal Colegiado de Circuito en Materia Administrativa Especializado en Competencia Económica, Radiodifusión y Telecomunicaciones, Final resolution of revision remedy 65/2014 filed by Hilda Graciela Rivera Flores, February 26, 2015, paragraphs 325 to 328 .

${ }^{35}$ Ibidem, paragraphs $333,334,342,345,351$ and 354 .

${ }^{36}$ See Ibidem, paragraphs 342, 354 and 357.
} 


\section{Special obligations of preponderant agents}

The determination of a preponderant agent by itself would not achieve any public interest objective, because knowing that an agent holds a certain market share does not correct market failures or prevents abuse of market power. Consequently, the special obligations imposed to preponderant agents are the instruments by virtue of which measures are established to prevent and deter any harm to competition.

The IFT imposed several special obligations to Grupo Televisa as a preponderant agent related with passive infrastructure sharing ${ }^{37}$, with audiovisual contents, with advertisement, and with information. This section will address audiovisual content and advertisement special obligations because those are directly connected with its market power in both free-to-air TV and pay TV.

\section{Relevant audiovisual content}

IFT determined a prohibition - to both telecom and broadcast preponderant agents -, to acquire relevant audiovisual content with exclusivity. Relevant audiovisual content would be that which is non-replicable and which is highly expected by the audience. The rationale expressed by the IFT was that because such type of content is non-replicable and highly expected, then a preponderant with its market power could affect competition if it had the exclusivity over relevant audiovisual content. A preponderant may acquire relevant audiovisual content provided it did not do so with an exclusivity clause. $^{38}$

\footnotetext{
${ }^{37}$ Passive infrastructure sharing is mandated for Grupo Televisa in favor of other free-toair TV station licensees, provided that they do not hold title of $12 \mathrm{MHz}$ or more in the coverage area. Grupo Televisa must have a public offer of such infrastructure, and is able to freely negotiate the price. In the event of disagreement between free-to-air TV licensees, then IFT will solve the dispute. Instituto Federal de Telecomunicaciones, Anexo 1 Medidas relacionadas con la compartición de infraestructura, contenidos, publicidad e información que son aplicables al GIETV en su carácter de agente económico preponderante en el sector de radiodifusión, http://www.ift.org.mx/iftweb/wp-content/uploads/2014/03/Anexo_1Resolucion_Preponderancia_TV.pdf, Second numbers 6 and 8, Third to Sixth.

${ }^{38}$ Instituto Federal de Telecomunicaciones, Acuerdo por el que el Pleno del Instituto Federal de Telecomunicaciones identifica los contenidos audiovisuales relevantes en términos y para los efectos de la medida Cuarta y el artículo segundo transitorio del anexo 4 de la resolución número P/IFT/EXT/060314/76 por la que se determinó al agente económico preponderante en el sector de telecomunicaciones y la medida Décimo Octava y el artículo tercero transitorio de la resolución número P/IFT/EXT/060314/77 por la que se determinó al agente económico preponderante en el sector de
} 
“(..) when the preponderant economic agents acquire in exclusivity the transmission rights of contents that are received by large parts of the audience and they are non-replicable, (...) they in fact eliminate the possibility that other participants may acquire such rights to use such contents, and consequently such act has the effect of strengthening their preponderant position before the audiences, as well as they limit the possibility of other participants to effectively compete with them." 39

Two questions immediately arose after IFT's preponderant resolution: (1) which were the so called relevant audiovisual contents, and (2) what would happen with those relevant contents that had already been acquired by preponderant agents with an exclusivity clause.

To answer the first question, the IFT took into account historical rating (audience index) of free-to-air TV and pay TV. IFT determined that only sports events held the non-replicable characteristic, because they had no similar substitute $^{40}$, and that only events with national coverage had the highly expected characteristic. At the end the following sports events were considered as relevant audiovisual content: all games of the Mexican men soccer team; inauguration and closing ceremonies of the Summer Olympic Games; inauguration, quarter finals, semifinals and final games of Soccer World Cup of FIFA; and final soccer games of the first division organized by the Mexican Football Federation (Liga MX). ${ }^{41}$

Previous to IFT's preponderant resolutions, Televisa had acquired the exclusive rights for the Mexican Republic to the Soccer World Cup of FIFA Russia 2018 and Qatar 2022; and América Móvil had acquired exclusive rights for the Mexican Republic to the Summer Olympic Games of Rio de Janeiro $2016 .^{42}$

radiodifusión, May 29, 2014, http://www.ift.org.mx/iftweb/wpcontent/uploads/2014/05/P_IFT_EXT_290514_105.pdf.

${ }^{39}$ Ibidem, pp. 3-4.

${ }^{40}$ For example, a soap opera, a reality show, etcetera, could be replicated by competitors, whereas sports events not.

${ }^{41}$ IFT, Lista de Contenidos Audiovisuales Relevantes, http://www.ift.org.mx/iftweb/wpcontent/uploads/2014/05/LISTA_DE_CONTENIDOS_AUDIOVISUALES_RELEVANT ES1.pdf (Consultation date: March 25, 2015).

${ }^{42}$ CNN Expansión, Televisa-AMóvil ¿adiós a las exclusivas?, March 11, 2014, http://www.cnnexpansion.com/negocios/2014/03/10/proximo-mundial-y-olimpicosexclusivos (Consultation date: March 25, 2015). 
Did the relevant audiovisual content exclusivity prohibition include the ones previously acquired? If yes, then the preponderant agents could argue that this prohibition was having retroactive effects against them and therefore was contrary to the Mexican Constitution. This argument could be offset by public interest reasons, which must prevail over private interest. If the answer were no, then how could IFT argue that the adverse effects on audience rights and upon competition would have to be borne until 2022? The IFT decided simply to ignore the issue. Its silence will certainly be used by the preponderant agents to preserve their current exclusivities referred to in last paragraph.

Finally, there are two criticisms to make to this prohibition. The first one is because in the case of Televisa, this prohibition is only for the free-to-air TV and could not be easily interpreted as to include Televisa's pay TV companies. Consequently, Televisa could acquire relevant audiovisual content in an exclusive manner through its pay TV companies, and that would not amount a violation to the special obligations imposed as a preponderant agent.

The second one is that the prohibition to acquire in an exclusive manner relevant audiovisual content is only for preponderant agents, without considering that audience rights could also be compromised by their acquisition by other corporate groups.

\section{Advertisement}

A preponderant special obligation regarding advertisement was imposed only to Televisa considering that it is linked with the provision of broadcast TV insofar as broadcast TV receives income to support its operations from the advertisers. The measure essentially obligates Televisa to have information regarding the terms and conditions for advertising on its free-to-air channels on its website. For such purposes Televisa must: include a model agreement; allow buying packages of free-to-air channels with other channels/programs of Televisa, or the possibility to acquire the right to retransmit a single channel; not discriminate, or refuse to enter into an agreement with a party interested in advertising in Televisa Channels. ${ }^{43}$

The criticism to such measure is that although the advertisement terms and conditions should be public, there is no way to identify whether Televisa is or is not discriminating. For example, in 2013 several non-governmental organizations requested Televisa, TV Azteca and other media companies to provide the terms and conditions to acquire advertisement space in their free-toair TV channels. The objective of the advertisement was to alert the population

${ }^{43}$ Instituto Federal de Telecomunicaciones, op. cit. 38 [Exhibit 1 to the Resolution of preponderant agent in the broadcast sector], Twenty first and Twenty second. 
of the risks of consuming soda and high-calorie beverages, and to promote water consumption. In the case of Televisa, there was never a response to the request. TV Azteca met with these NGOs, but afterwards responded they had no time left for advertisements. ${ }^{44}$ It is to be noted that soda and high-calorie food (junk food) are of the main advertisers on TV, and that Mexico has high levels of obesity among its population.

Whether the refusal to give space in free-to-air channels to this type of advertisements was a legitimate one (e.g. there is no time left for more ads) or was it a discrimination so that the major advertisers (e.g. soda companies) would not be upset, is not clear. However, this case evidences the need of having an electronic system so that Televisa would receive requests for advertisements and avoid any discrimination, or at least, provide a way of detecting discrimination. This type of system would have been the equivalent of the electronic system for interconnection matters for America Móvil as the telecom preponderant, whereby each request is filed and must be processed in the order it was received.

\section{Final remarks}

The courts confirmation of Televisa and its independent affiliates as preponderant in free-to-air TV is a milestone for telecommunication and antitrust in Mexico. Although the high concentration of Televisa in free-to-air TV has a long establish tradition of several decades, this is the first time that an antitrust instrument (preponderant agent) has confirmed it. The declaration of Televisa as preponderant by itself would mean nothing, without the special obligations.

The effectiveness of the special obligations imposed to Televisa as a freeto-air TV broadcaster is yet to be demonstrated. First because the special obligations (e.g. relevant audiovisual content exclusivity prohibition) do not apply to Televisa's pay TV companies. Second because the provisions for advertisement on free-to-air TV do not have mechanisms for demonstrating whether or not Televisa discriminates or refuses to enter into advertisement agreements with certain companies for different reasons (e.g. oust potential competitors, deny ads to persons with conflicting interests with major advertisers). Third because in Mexico law enforcement is still a major challenge, and affirming that Mexico is a real rule of law country is debatable.

Also, one of the main problems for Mexican society and democracy are the lack of plurality and diversity on $\mathrm{TV}$, which were not addressed at all in

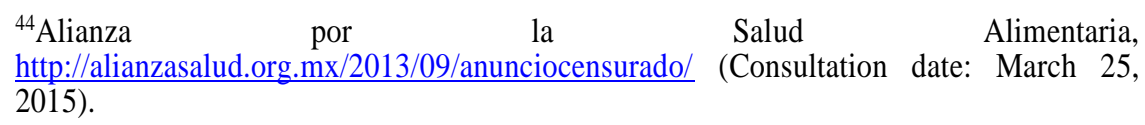


IFT's preponderant resolution. Plurality and diversity could improve democracy quality because the people would be able to receive information from different sources and ideologies, they could confront them and then form their own opinion in a free manner. Limited public entities free-to-air TV stations and very limited real independent local channels, are unable to cope the high concentration of $90 \%$ of audience share by Televisa and TV Azteca. This fact cannot be ignored when $94.9 \%$ of Mexican homes have $\mathrm{TV}^{45}$, and $73 \%$ of Mexicans obtain information through TV. ${ }^{46}$ Pro-plurality special obligations could have been to oblige Televisa to include a news program developed by independent journalists, for example.

Notwithstanding the above, the court's resolutions regarding preponderant agents set forth several triumphs for the IFT as the telecom regulator. Regulatory deference with light scrutiny appears to be the future of courts' decisions, as long as the IFT demonstrates it is exercising its discretionary competencies with technical/economic issues, its decisions are reasonable and proportional to the objectives set by the Constitution or by the law.

Finally, it is important to note that on March 2015, for the first time ever in Mexico, a public bid for free-to-air TV stations with national coverage was

\footnotetext{
${ }^{45}$ Instituto Nacional de Estadística y Geografía, "Hogares con equipamiento de tecnología de información y comunicaciones por tipo de equipo, 2001 a 2014", http://www3.inegi.org.mx/sistemas/temas/default.aspx?s=est\&c=19007 (Consultation date: March 15, 2015).

${ }^{46}$ Instituto Federal de Telecomunicaciones, citing a research by Parametría on page 306 of the "Resolución mediante la cual el Pleno del Instituto Federal de telecomunicaciones determina al grupo de interés económico del que forman parte Grupo Televisa S.A.B., Canales de Televisión Populares, S.A. de C.V., Radio Televisión, S.A. de C.V., Radiotelevisora de México Norte, S.A. de C.V., T.V. de los Mochis, S.A. de C.V., Teleimagen del Noroeste, S.A. de C.V., Televimex, S.A. de C.V., Televisión de Puebla, S.A. de C.V., Televisora de Mexicali, S.A. de C.V., Televisora de Navojoa, S.A., Televisora de Occidente, S.A. de C.V., Televisora Peninsular, S.A. de C.V., Mario Enríquez Mayans Concha, Televisión La Paz, S.A., Televisión de la Frontera, S.A., Pedro Luis Fitzmaurice Meneses, Telemisión, S.A. de C.V., Comunicación del Sureste, S.A. de C.V., José de Jesús Partida Villanueva, Hilda Graciela Rivera Flores, Roberto Casimiro González Treviño, TV Diez Durango, S.A. de C.V., Televisora de Durango, S.A. de C.V., Corporación Tapatía de Televisión, S.A. de C.V., Televisión de Michoacán, S.A. de C.V., José Humberto y Loucille, Martínez Morales, Canal 13 de Michoacán, S.A. de C.V., Televisora XHBO, S.A. de C.V., TV Ocho, S.A. de C.V., Televisora Potosina, S.A. de C.V., TV de Culiacán, S.A. de C.V., Televisión del Pacífico, S.A. de C.V., Tele-Emisoras del Sureste, S.A. de C.V., Televisión de Tabasco, S.A. y Ramona Esparza González, como agente económico preponderante en el sector radiodifusión y le impone las medidas necesarias para evitar que se afecte la competencia y la libre concurrencia", March 6, 2014. See www.ift.org.mx/iftweb/sector-de-radiodifusion/.
} 
concluded. ${ }^{47}$ There were two participants. Each won a license to operate $6 \mathrm{MHz}$ for digital TV until 2035. ${ }^{48}$ Would the entrance of these two new Televisa's competitors change IFT determination of Televisa as a preponderant agent? As the IFT considered two variables for determining Televisa as preponderant, namely, audience share (67\%) and users per network capacity (54\%), then IFT would have to at least evidence that Televisa's audience share would continue to be more than $50 \%$ in the Mexican Republic. In the near future, it is unlikely that Televisa's audience share is reduced in a significant manner. Had IFT considered also plurality and diversity as rationales for determining Televisa as preponderant, then IFT would most certainly have arguments for maintaining this special regime upon Televisa. However, as IFT relied only on competition rationales, preponderant special obligations might have to be eventually revised.

\section{References}

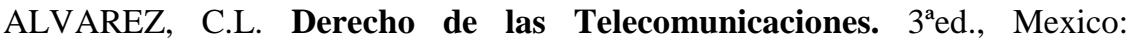
Fundalex and Posgrado de Derecho de la UNAM, 2013, http://claraluzalvarez.org/wp-content/uploads/2014/10/Clara-LuzAlvarez-Dcho-Telecom-2013-final.pdf.

CÁMARA DE DIPUTADOS (Comisión de Puntos Constitucionales), Propuestas de modificación al Dictamen de la Comisión de Puntos Constitucionales con proyecto de Decreto por el que se reforman $y$ adicionan diversas disposiciones de la Constitución Política de los Estados Unidos Mexicanos en materia de telecomunicaciones, March 21, 2013.

. Proyecto de Dictamen en sentido positivo a la iniciativa con proyecto de Decreto que reforma y adiciona diversas disposiciones de los artículos $6^{o}, 7^{o}, 27,28,73,79$ y 94 de la Constitución Política de los Estados Unidos Mexicanos, en materia de telecomunicaciones, March 15, 2013.

Decreto por el que se reforman y adicionan diversas disposiciones de los

\footnotetext{
${ }^{47}$ Instituto Federal de Telecomunicaciones, IFT-1 Licitación de dos cadenas de televisión radiodifundida digital, http://www.ift.org.mx/iftweb/industria-intermedia/unidad-desistemas-de-radio-y-television/licitaciones-en-curso-radio-y-television/licitacion-ift-1/ (Consultation date: March 31, 2015).

${ }^{48}$ As of the date of this article, the IFT had already granted the license for Cadena Tres, and the license for Grupo Radio Centro was not yet granted as payment of the license fee was pending.
} 
artículos $6^{\circ}, 7^{\circ}, 27,28,73,78,94$ y 105 de la Constitución Política de los Estados Unidos Mexicanos, [Decree by which several provisions of articles $6^{\circ}, 7^{\circ}, 27,28,73,78,94$ and 105 of the Political Constitution of the United Mexican States are amended or added], published in the Federal Official Daily on June 11, 2013.

EUROPEAN UNION, Directiva 98/10/CE del Parlamento Europeo y del Consejo de 26 de febrero de 1998 sobre la aplicación de la oferta de red abierta (ONP) a la telefonía vocal y sobre el servicio universal de telecomunicaciones en un entorno competitivo, published on the European Communities Official Daily L 101/24 ES on April 1, 1998, http://www.boe.es/doue/1998/101/L00024-00047.pdf (Consultation date: March 15, 2015).

Directive 2002/21/EC of the European Parliament and of the Council of 7 March 2002 on a common regulatory framework for electronic communications networks and services (Framework Directive), number 25 , http://eur-lex.europa.eu/legalcontent/EN/TXT/PDF/?uri=CELEX:02002L0021-

20090702\&from=EN (Consultation date: March 15, 2015).

INSTITUTO FEDERAL DE TELECOMUNICACIONES, Acuerdo por el que el Pleno del Instituto Federal de Telecomunicaciones identifica los contenidos audiovisuales relevantes en términos y para los efectos de la medida Cuarta y el artículo segundo transitorio del anexo 4 de la resolución número P/IFT/EXT/060314/76 por la que se determinó al agente económico preponderante en el sector de telecomunicaciones y la medida Décimo Octava y el artículo tercero transitorio de la resolución número P/IFT/EXT/060314/77 por la que se determinó al agente económico preponderante en el sector de radiodifusión, May 29, 2014, http://www.ift.org.mx/iftweb/wp-

content/uploads/2014/05/P_IFT_EXT_290514_105.pdf.

. Anexo 1 Medidas relacionadas con la compartición de infraestructura, contenidos, publicidad e información que son aplicables al GIETV en su carácter de agente económico preponderante en el sector de radiodifusión, http://www.ift.org.mx/iftweb/wpcontent/uploads/2014/03/Anexo_1-Resolucion_Preponderancia_TV.pdf.

IFT-1 Licitación de dos cadenas de televisión radiodifundida digital, http://www.ift.org.mx/iftweb/industria-intermedia/unidad-de-sistemasde-radio-y-television/licitaciones-en-curso-radio-y-television/licitacionift-1/ (Consultation date: March 31, 2015). 
Informe estadístico 3 Trimestre 2014, http://www.ift.org.mx/iftweb/wpcontent/uploads/2015/03/InformeEstadisticoVF.pdf.

Resolución mediante la cual el Pleno del Instituto Federal de Telecomunicaciones determina al grupo de interés económico del que forman parte América Móvil, S.A.B. de C.V., Teléfonos de México, S.A.B. de C.V., Teléfonos del Noroeste, S.A. de C.V., Radiomóvil Dipsa, S.A.B. de C.V., Grupo Carso, S.A.B. de C.V., y Grupo Financiero Inbursa, S.A.B. de C.V., como agente económico preponderante en el sector de telecomunicaciones y le impone las medidas necesarias para evitar que se afecte la competencia y la libre concurrencia, Pleno, V Sesión Extraordinaria, P/IFT/EXT/060314/76, March 6, 2014, www.ift.org.mx/iftweb/sector-de-telecomunicaciones/) (Consultation date: (November 20, 2014).

- Resolución mediante la cual el Pleno del Instituto Federal de Telecomunicaciones determina al grupo de interés económico del que forman parte Grupo Televisa S.A. B., Canales de Televisión Populares, S.A. de C.V., Radio Televisión, S.A. de C.V., Radiotelevisora de México Norte, S.A. de C.V., T.V. de los Mochis, S.A. de C.V., Teleimagen del Noroeste, S.A. de C.V., Televimex. S.A. de C.V., Televisión de Puebla, S.A. de C.V., Televisora de Mexicali, S.A. de C.V., Televisora de Navojoa, S.A., Televisora de Occidente, S.A. de C.V., Televisora Peninsular, S.A. de C.V., Mario Enríquez Mayans Concha, Televisión La Paz, S.A., Televisión de la Frontera, S.A., Pedro Luis Fitzmaurice Meneses, Telemisión, S.A. de C.V., Comunicación del Sureste, S.A. de C.V., José de Jesús Partida Villanueva, Hilda Graciela Rivera Flores, Roberto Casimiro González Treviño, TV Diez Durango, S.A. de C.V., Televisora de Durango, S.A. de C.V., Corporación Tapatía de Televisión, S.A. de C.V., Televisión de Michoacán, S.A. de C.V., José Humberto y Loucille, Martínez Morales, Canal 13 de Michoacán, S.A. de C.V., Televisora XHBO, S.A. de C.V., TV Ocho, S.A. de C.V., Televisora Potosina, S.A. de C.V., TV de Culiacán, S.A. de C.V., Televisión del Pacífico, S.A. de C.V., Tele-Emisoras del Sureste, S.A. de C.V., Televisión de Tabasco, S.A. y Romana Esparza González, como agente económico preponderante en el sector radiodifusión y le impone las medidas necesarias para evitar que se afecte la competencia y la libre concurrencia, Pleno, V Sesión Extraordinaria 2014, P/IFT/060314/77, March 6, 2014, p. 408, http://apps.ift.org.mx/publicdata/P_IFT_EXT_060314_77.pdf

(Consultation date: Nov. 11, 2014). 
INSTITUTO FEDERAL DE TELECOMUNICACIONES (AUTORIDAD INVESTIGADORA), Datos relevantes del Dictamen Preliminar sobre la Existencia de Poder Sustancial en el Mercado Relevante de Provisión del Servicio de Televisión y Audio Restringidos, radicado en el Expediente AI/DC-001-2014, published in the Federal Official Daily on March 18, 2015.

PEÑA NIETO, E., Iniciativa de Decreto que reforma y adiciona diversas disposiciones de la Constitución Política de los Estados Unidos Mexicanos, presented by president Enrique Peña Nieto to the Mexican Deputy Chamber on March 11, 2013.

Primer Tribunal Colegiado de Circuito en Materia Administrativa Especializado en Competencia Económica, Radiodifusión y Telecomunicaciones, Final resolution of revision remedy 65/2014 filed by Hilda Graciela Rivera Flores, February 26, 2015.

ROLDÁN XOPA, J. Derecho Administrativo. Mexico: Oxford University Press, 2008.

SENADO DE LA REPÚBLICA, Dictamen de las Comisiones Unidas de Puntos Constitucionales; de Comunicaciones y Transportes; de Radio, Televisión y Cinematografía y de Estudios Legislativos, con la opinión de las Comisiones de Gobernación y de Justicia, respecto de la Minuta con proyecto de Decreto por el que se reforman y adicionan diversas disposiciones de la Constitución Política de los Estados Unidos Mexicanos en materia de telecomunicaciones, April 23, 2013. 